\title{
History of Education Society 2005 Outstanding Book Award
}

The History of Education Society has selected Jack Dougherty's More Than One Struggle: The Evolution of Black School Reform in Milwaukee to receive the Society's Outstanding Book Award for 2005. The award is given annually to the best book in the history of education published in the previous year. A distinguished committee of scholars in the field selected the book from a large number of books that were nominated for this award. The members of the committee were William Cutler (Temple University), chair, Thomas Ewing (Virginia Tech University), and Karen Graves (Denison University). The award comes with a check for $\$ 1,000$. We will honor the award winner at the annual meeting in Baltimore.

The committee also selected two books for honorable mention. They are: Advancing Democracy: African Americans and Their Struggle for Access and Equity in Higher Education in Texas by Amilcar Shabazz; and The Strange Career of Bilingual Education in Texas, 1836-1981 by Carlos K. Blanton. We offer our congratulations to Jack Dougherty, Amilcar Shabazz, and Carlos Blanton for their scholarly achievement-and our thanks to the committee for their fine work in carrying out this review. 